\title{
Drivers of change in groundwater resources: a case study of the Indian Punjab
}

Article

Accepted Version

Singh, S. and Park, J. (2018) Drivers of change in groundwater resources: a case study of the Indian Punjab. Food Security, 10 (4). pp. 965-979. ISSN 1876-4517 doi:

https://doi.org/10.1007/s12571-018-0823-2 Available at https://centaur.reading.ac.uk/78157/

It is advisable to refer to the publisher's version if you intend to cite from the work. See Guidance on citing.

To link to this article DOI: http://dx.doi.org/10.1007/s12571-018-0823-2

Publisher: Springer

All outputs in CentAUR are protected by Intellectual Property Rights law, including copyright law. Copyright and IPR is retained by the creators or other copyright holders. Terms and conditions for use of this material are defined in the End User Agreement.

$\underline{\text { www.reading.ac.uk/centaur }}$

\section{CentAUR}


Central Archive at the University of Reading

Reading's research outputs online 
Title:

2 Drivers of Change in Groundwater Resources: A Case Study of the Indian Punjab

3 Authors: Sukhwinder Singh ${ }^{1}$, Julian Park ${ }^{2}$

$4 \quad{ }^{1}$ Postdoctoral Fellow, School for Environment and Sustainability, University of Michigan, Ann Arbor, USA;

5 Corresponding author: (sukhrec@yahoo.com); ORCID ID: 0000-0003-3681-5511

6

${ }^{2}$ Professor and Head, School of Agriculture, Policy and Development, University of Reading, UK

7

8

9

10

11

12

13

14

15

16

17

18

19

20

21

22

23 
Groundwater Resources in the Indian Punjab

24

25

\section{Introduction}

The Indian Punjab, a strategically important region from India's national food security standpoint, produces 19\% and $11 \%$ of India's total wheat and rice production respectively, and has been contributing about $25-50 \%$ of rice and 38 $75 \%$ of wheat to India's central pool of food grains for the last four decades (PSFC 2013). To note, from the central pool, food is distributed to the poorest across India through the national public distribution system.

Punjab's agro-climatic conditions allow its farmers to cultivate their land at least twice a year i.e. during the Rabi (winter) and the Kharif (summer) seasons ${ }^{1}$ (Pede et al. 2012). Wheat and rice are the major Rabi and Kharif crops of Punjab respectively. However, despite Punjab having higher productivity levels than the respective national averages ${ }^{2}$, many of its farmers are facing various socio-economic challenges associated with a slowdown in agricultural growth, thus, resulting in reduced net farm incomes. Increased cost of cultivation, particularly related to seeds, fertilizers, pesticides, diesel and labor, is one of the major drivers of this falling trend in farm incomes (Kalkat et al. 2006; Singh 2012). Additionally, Singh (2012a) and Sarkar and Das (2014) argued that the current farming systems are depleting the groundwater reservoirs, leading to long-term ecological implications for the overall sustainability of farming enterprises in Punjab.

Nearly $100 \%$ of Punjab's farmed area is irrigated, of which, $73 \%$ is irrigated through groundwater resources (GoP 2012). Most of the canal-irrigated areas lie in the south-western zone of Punjab where the groundwater is brackish and unfit for irrigational purposes although in some regions, the groundwater is used in conjunction with canal water (Tiwana et al. 2007; Sidhu et al. 2011).

Looking at the recent demand and supply equation (as on 2009), the net annual groundwater demand (irrigation, domestic and industrial use) in Punjab was 34.66 billion cubic metres against an availability of 20.35 billion cubic

1 The Rabi (winter) growing season runs from November/December through April with the major crops being wheat, barley, oilseeds and millet. The Kharif season refers to the summer growing period from May to November with rice, corn, and cotton as the major crops.

2 Punjab's average yield of wheat and rice in 2010-11 was 4.7 and 3.7 tonnes/ha compared with 2.9 and 3.2 at national level respectively. However, the respective world averages were 3.1 and 4.3 (GoP 2012). 
metres. The deficit of 14.31 billion cubic metres is essentially met through the overwithdrawal of groundwater resources (CGWB 2013). About 2.95 million hectares (ha) out of Punjab's net sown area of 4.07 million ha, is irrigated via 1.38 million tubewells, of which, $82 \%$ are electricity operated utilizing approximately $31 \%$ of Punjab's total electricity consumption (GoP 2012). In 2010-11, Punjab's farm sector received Rs 32.6 billion (INR) as electricity subsidy, which was approximately 7.4\% of Punjab's total Net State Domestic Product (NSDP) from agriculture and allied activities at current prices (Singh 2012a; GoP 2012). Further, Punjab government has recently decided to release permissions for a further 0.11 million tubewell connections in a phased manner, that will place an additional burden of INR 6.7 billion on the state exchequer (Sood 2014). as 172\% in Punjab (higher than all Indian states) compared with 133\% and 137\% in the adjoining states of Haryana and Rajasthan respectively, and $62 \%$ at the national level. The percentage of over-exploited blocks ${ }^{4}$ increased from 53\% in 2000 to $80 \%$ in 2011 (Table 1).

Table 1 Number of development blocks (\%) under different categories of groundwater exploitation in Punjab: 2000 to 2011

\begin{tabular}{|l|c|c|c|}
\hline \multicolumn{1}{|c|}{ Category } & $\mathbf{2 0 0 0}$ & $\mathbf{2 0 0 4}$ & $\mathbf{2 0 1 1}$ \\
\hline Over-exploited & 53 & 75 & 80 \\
\hline Critical & 7 & 3 & 3 \\
\hline Semi-critical & 12 & 3 & 1 \\
\hline Safe & 28 & 19 & 16 \\
\hline
\end{tabular}

59 Sources: Tiwana et al. (2007); CGWB (2006; 2014)

60 In particular, the level of groundwater in central zone is depleting relatively faster than in the other two zones. For $^{5}$ 61 instance, nine districts in this zone have a majority of blocks in the over-exploited category. The annual rate of 62 groundwater depletion in the nine central districts is $75 \mathrm{~cm}$ compared with $55 \mathrm{~cm}$ across Punjab as a whole (Tiwana

3 Stage of groundwater development $=$ Existing gross draft for all uses/Net annual availability *100 (CGWB 2011).

4 Block is an administrative unit used for rural planning in India. A block covers several villages. In 2009, Punjab had 20 districts, 141 blocks and 12,278 inhabited villages (GoP 2009).

5 Punjab can be broadly divided into three agro climatic regions, sub-mountainous (zone I), central (zone II), and southwestern (zone III) covering 17\%, 47\%, and 36\% of the land area respectively (Sidhu and Vatta nd). 
63 et al., 2007; Singh, 2012a). Further, this zone covers more than half of the land area of Punjab and contains $70 \%$ of total tubewells. Here, $72 \%$ of the land area is under rice, of which, about $80 \%$ is irrigated using groundwater resources

65 (GoP, 2012a). In fact, Rodell et al. (2009) estimated that the groundwater in Punjab depleted at a mean rate of $4.0 \pm$ $1.0 \mathrm{~cm}$ annually between 2002 and 2008, and termed this phenomenon 'as the largest mining of water on earth.' However, the phenomenon of over-exploitation of groundwater resources is not only limited to Indian Punjab but also common in many parts of the world as it is really difficult to regulate the pumping of groundwater resources and realize its equitable distribution across all users (De Fraiture and Giordanob 2013; Hoogesteger and Wester 2015).

When considering the crop water requirements within both the cropping seasons, the relative water requirements of

71 wheat are comparable to other Rabi crops. However, rice (including basmati ${ }^{6}$ ) is the most water-intensive crop of the

72 Kharif season $^{7}$ (Singh 2012a), which is cultivated on 68\% of Punjab's net sown area (GoP 2013) using a mixture of

73 surface and groundwater sources ${ }^{8}$. Most rice growers use conventional irrigation techniques such as flood irrigation

74 and puddling ${ }^{9}$ (Singh 2009a; Larson et al. 2013). In India, only 22\% of the total water saving technologies released in the last 40 years has been successfully transferred to farmers and their success rate (adopted and approaved by farmers) was only $12 \%$ (Palanisami et al. 2015). In Punjab, which is one of the agriculturally advanced states of India with high levels of subsidies on water saving technologies, the adoption of these technologies is limited. For instance, the laser leveler, which is the water saving technology most widely available on rent, was used by only one-seventh of the

79 farmers in Punjab (Larson et al. 2013) and the adoption of other precision technologies, e.g. drip irrigation, SRI

80 (System of Rice Intensification), direct seeding, zero-tillage is also limited.

6 Here, rice refers to an ordinary variety of rice whereas basmati is a premium variety of long-grain Indian rice with a delicate fragrance.

7 Over the Kharif season, rice and basmati, on average, require 22 and 15 irrigations respectively when compared to other popular Kharif crops such as cotton, sugarcane and maize which, on average, need 6, 14 and 5 irrigations respectively. In the Rabi season, wheat requires 5 irrigations compared to 4,8 and 12 irrigations for mustard, winter maize and spring maize respectively (Singh 2012a).

8 To note, surface water sources cover the south-western region and some parts of the central region only.

9 Puddling is a process of making the upper surface of the rice field hard enough to keep the water standing in the rice field (Singh and Kaur 2012). 
81 Considering the supply side, amount of rainfall and land area irrigated by canals have declined in Punjab by $14 \%$ and

82 27\%, respectively between 1990 and 2010 (GoP 2012). For instance, the annual rainfall was 754 mm, 392 mm and

$83472 \mathrm{~mm}$ in 1990, 2000 and 2010, respectively, whereas the net area irrigated by surface water resources (e.g. canals)

84 came down from 1,660 to 1,113 thousand hectare between 1990-91 and 2010-11 in Punjab. As Srivastava et al. (2015)

85 argued that unlike India, rainfall in Punjab has a limited role to play in recharging the groundwater due to low annual

86 precipitation. Moreover, rainfall in Punjab recharges only 32\% of replenishable groundwater against $74 \%$ at national

87 level. In Punjab, other sources, e.g. return flow from irrigation, seepage from canal, recharge from tanks, ponds and

88 water conservation structures, supply the remaining groundwater recharge. Thus, artificial groundwater recharging

89 and integrated water resources management can play a decisive role in improving groundwater supply. The CGWB

90 (2013a) reported that about $86 \%$ of the land area (43,340 out of 50,362 sq. km) in Punjab is feasible for artificial

91 recharge and planned 4,54,924 artificial recharge structures (rural and urban) for the state. However, Srivastava et al.

92 (2015) argue that artificial groundwater recharge alone cannot help much in sorting out Punjab's groundwater

93 sustainability crisis as the CGWB (2013a) estimated that the quantity of non-committed surplus surface water in

94 Punjab for artificial recharge is 1201 million cubic metres (MCM) against the requirement of 70,071 MCM. Further,

95 integrated water resources management has a limited scope as interlinked nature of groundwater and surface water is

96 not recognized in India. For instance, more than $60 \%$ tube wells were constructed outside the command area of surface

97 irrigation and less than $1 \%$ of the total wells were used for augmenting groundwater supplies. Thus, there is a limited

98 scope of augmenting groundwater supplies through artificial groundwater recharge and integrated water resource use,

99 withdrawal of groundwater for agricultural use should be curtailed as agriculture sector consumes about $98 \%$ of

100 groundwater in Punjab (Srivastava et al. 2015).

101 In fact, the groundwater withdrawal could depend on a range of socio-economic factors in addition to the crops grown

102 and their cultivation methods. These are in part shaped in response to the policy framework, especially the Minimum

103 Support Price and Assured Purchase (MSPAP) and provision of free electricity to the farm sector. However, there is

104 a general consensus that an expansion of the area under rice has largely contributed to the depletion of groundwater

105 in Punjab (Singh 2009; 2012a; Sarkar and Das 2014). The MSPAP policy and input subsidy regime, especially

106 unlicensed groundwater availability and free-of-cost electricity to pump it out, are encouraging farmers to adopt simple

107 wheat-rice rotations to the exclusion of other more diversified options (Singh 2013; 2016). For instance, between 
Groundwater Resources in the Indian Punjab

108

109

110

111

112

113

114

115

116

117

118

119

120

121

122

123

124

125

126

127

128

129

130

131

1980-81 and 2011-12, the proportion of land area under wheat and rice in Punjab increased from 59\% to 80\% (GoP 2012).

The consistent use of this rotation for the last four decades has gradually led to a reduction in crop diversity ${ }^{10}$ in most regions of Punjab (Singh and Sidhu, 2004; Sidhu and Vatta, n.d.; Singh and Benbi 2016). Although the State government has been encouraging farmers to diversify to high-value crops since 1986, it has had little success (Sarkar and Das 2014) because wheat and rice are more effectively priced and have a lower productivity risk compared with alternative crops that have been suggested under various diversification plans to-date (Singh 2013; Shergill 2013). Another driver could be a poor performance of agricultural research and development institutions, both at the national and state levels, as they have failed to prescribe an alternative set of crops with similar or lower productivity risks to wheat and rice to farmers (Singh 2016).

Punjab government had enacted and implimented "The Punjab Preservation of Sub Soil Water Act, 2009" in 2009 which forbids farmers to transplant rice before $10^{\text {th }}$ June (Singh 2009), which has now been extended to $15^{\text {th }}$ June. Recently, the national government's Ministry of Water Resources has advised the Indian states to enact the Ground Water Legislation to regulate and control the development of groundwater (Kulkarni and Shah 2013) but the Punjab government has not done anything in this regard although a neighboring state of Himachal Pradesh had already enacted and implemented it (see www.cgwb.gov.in).

Concerns regarding the socio-economic, environmental and food security impacts of current farm related trends in the Indian Punjab suggest a nuanced understanding of groundwater resources and socio-economic drivers for its use is needed. The theoretical framework of this study is underpinned around the fact that the existing research explains the groundwater depletion in Punjab from two perspectives only:

(a) Policy perspective i.e. Centre and State government policies, particularly related to production oriented subsidies and marketing and procurement of crops;

(b) Technological perspective i.e. relative water requirements of existing and suggested crops, and adoption and efficiency of water conservation technologies.

10 Crop diversification index dropped from 0.75 in 1975-76 (Sidhu et al., 2010) to 0.42 in 2009-10 (Singh and Benbi 2016) 
132 However, no study in the existing literature has discussed the socio-economic factors affecting farmers' decisions 133 about 'which crops to cultivate and how they are to be grown' that eventually affect the groundwater withdrawal.

134 Against this backdrop, this paper evaluates the current situation in Punjab using data collected through a field survey 135 of 120 farmers spread across three agro-climatic zones of Punjab, and outlines the major socio-economic (farm-and 136 farmer-specific) factors (cause) that have a significant association with the change in the level of groundwater (effect) 137 in this region.

\section{Material and Methods}

In October-November 2010 (Singh and Benbi $2016^{11}$ ), a survey of 120 farmers was conducted across three districts, namely Gurdaspur, Barnala and Ferozepur, of the Indian Punjab. A multistage cluster sampling technique was used to select districts, blocks and then farmers. To start with, a Farming Intensity Index (FII) was calculated (Table 2) for

142 each of the 20 districts of Punjab using the major indicators of agricultural sustainability in Punjab, e.g., per hectare 143 agricultural production in value terms, condition of the underground water resources, state of soil health and Crop144 Diversification Index (CDI). The data used to realize the FII components (Table 2) were largely calculated using

145 secondary resources. For instance, agricultural production/hectare (in Rs) and Crop Diversification Index (CDI) were 146 calculated from Statistical Abstract of Punjab (GoP 2012) whereas groundwater development data was taken from

147 CGWG (2012). The district-wise data on Soil Organic Carbon were calculated under the guidance of Professor Dinesh

148 Benbi using the soil unit database available at the Department of Soil Science, Punjab Agricultural University, 149 Ludhiana.

150 The CDI was calculated using 1-H, where $\mathrm{H}$ is Hirschman-Herfindahl Index $(\mathrm{HHI})^{12}$ measured as:

$$
H=\sum_{i=1}^{N} s_{i}^{2}
$$

152 where

11 This paper is based on the same field survey that I, as the first author, used in my paper Singh and Benbi (2016). Thus, some contents of this paper, e.g. Material and methods, and farmer profile, might look identical to Singh and Benbi (2016).

12 This index takes a value of 1 when there is complete concentration and approaches zero when diversification is 'perfect'. A higher CDI indicates greater crop diversity in production patterns (Singh and Sidhu 2004). 
Groundwater Resources in the Indian Punjab

$153 \mathrm{~N}$ is the total number of crops

154 Si represents area proportion of the i-th crop in total cropped area

155 Table 2 Calculation of a district-wise Farming Intensity Index (FII) using major agricultural sustainability indicators 156 for the Indian Punjab

\begin{tabular}{|c|c|c|c|c|c|c|c|c|c|c|c|c|c|c|c|c|}
\hline \multirow{2}{*}{ Sr. No } & \multirow{2}{*}{ District } & \multicolumn{3}{|c|}{ Production / Hectare (in Rs) } & \multicolumn{4}{|c|}{ Groundwater Development (\%) } & \multicolumn{3}{|c|}{ Crop Diversification Index (CDI) } & \multicolumn{2}{|c|}{ Soil Organic Carbon } & $(\%)$ & \multirow{2}{*}{$\begin{array}{c}\text { Farming } \\
\text { Intensity } \\
\text { Index } \\
\text { (FII) }\end{array}$} & \multirow{2}{*}{$\begin{array}{l}\text { Overall } \\
\text { Ranking }\end{array}$} \\
\hline & & $x^{+}$ & $\mathbf{X}-\overline{\mathbf{x}}$ & $(\mathbf{X}-\overline{\mathbf{x}}) / \mathrm{SD}$ & $x$ & $\mathbf{X}-\overline{\mathbf{x}}$ & $(\mathbf{X}-\overline{\mathbf{x}}) / \mathrm{SD}$ & Inverse $\S$ & $x$ & $\mathbf{X}-\overline{\mathbf{x}}$ & $(\mathbf{X}-\overline{\mathbf{x}}) / \mathbf{S D}$ & $x$ & $\mathbf{X}-\overline{\mathbf{x}}$ & $(\mathrm{X}-\overline{\mathbf{x}}) / \mathrm{SD}$ & & \\
\hline & & & & A & & & & B & & & C & & & $\mathrm{D}$ & $\mathrm{A}+\mathrm{B}+\mathrm{C}+\mathrm{D}$ & \\
\hline 1 & Sangrur & 65002 & 8586 & 1.11 & 183 & 36 & 0.71 & -0.71 & 0.60 & -0.05 & -1.09 & 0.44 & 0.02 & 0.43 & -0.26 & 13 \\
\hline 2 & Patiala & 60818 & 4402 & 0.57 & 165 & 18 & 0.36 & -0.36 & 0.59 & -0.06 & -1.16 & 0.47 & 0.05 & 1.13 & 0.18 & 9 \\
\hline 3 & Ludhiana & 69145 & 12729 & 1.65 & 144 & -3 & -0.05 & 0.05 & 0.61 & -0.03 & -0.69 & 0.49 & 0.07 & 1.54 & 2.55 & 3 \\
\hline 4 & Moga & 62821 & 6405 & 0.83 & 178 & 31 & 0.61 & -0.61 & 0.58 & -0.07 & -1.47 & 0.40 & -0.02 & -0.48 & -1.73 & 17 \\
\hline 5 & Ferozpur & 58604 & 2188 & 0.28 & 105 & -42 & -0.81 & 0.81 & 0.68 & 0.03 & 0.56 & 0.47 & 0.05 & 1.06 & 2.71 & 2 \\
\hline 6 & Amritsar & 48385 & -8031 & -1.04 & 152 & 5 & 0.10 & -0.10 & 0.60 & -0.04 & -0.90 & 0.52 & 0.10 & 2.16 & 0.12 & 10 \\
\hline 7 & Kapurthala & 61381 & 4965 & 0.64 & 204 & 57 & 1.12 & -1.12 & 0.65 & 0.00 & 0.03 & 0.38 & -0.04 & -0.93 & -1.37 & 16 \\
\hline 8 & Jalandhar & 53572 & -2844 & -0.37 & 254 & 107 & 2.09 & -2.09 & 0.68 & 0.03 & 0.66 & 0.42 & -0.01 & -0.14 & -1.94 & 18 \\
\hline 9 & Gurdaspur & 45015 & -11401 & -1.47 & 107 & -40 & -0.77 & 0.77 & 0.63 & -0.02 & -0.47 & 0.42 & 0.00 & 0.05 & -1.12 & 15 \\
\hline 10 & Taran Taran & 48385 & -8031 & -1.04 & 200 & 53 & 1.04 & -1.04 & 0.59 & -0.06 & -1.20 & 0.39 & -0.03 & -0.62 & -3.90 & 20 \\
\hline 11 & Barnala & 65002 & 8586 & 1.11 & 202 & 55 & 1.08 & -1.08 & 0.61 & -0.04 & -0.72 & 0.35 & -0.07 & -1.54 & -2.22 & 19 \\
\hline 12 & Faridkot & 58046 & 1630 & 0.21 & 106 & -41 & -0.79 & 0.79 & 0.63 & -0.02 & -0.46 & 0.40 & -0.02 & -0.48 & 0.06 & 11 \\
\hline 13 & Mohali & 44593 & -11823 & -1.53 & 88 & -59 & -1.14 & 1.14 & 0.69 & 0.04 & 0.87 & 0.40 & -0.02 & -0.48 & 0.00 & 12 \\
\hline 14 & Fatehgarh Sahib & 63515 & 7099 & 0.92 & 161 & 14 & 0.28 & -0.28 & 0.61 & -0.04 & -0.83 & 0.49 & 0.07 & 1.50 & 1.31 & 4 \\
\hline 15 & Mansa & 58906 & 2490 & 0.32 & 175 & 28 & 0.55 & -0.55 & 0.69 & 0.04 & 0.83 & 0.37 & -0.05 & -1.16 & -0.56 & 14 \\
\hline 16 & Bathinda & 57613 & 1197 & 0.15 & 93 & -54 & -1.04 & 1.04 & 0.70 & 0.05 & 1.03 & 0.38 & -0.04 & -0.97 & 1.26 & 5 \\
\hline 17 & Muktsar & 60394 & 3978 & 0.51 & 62 & -85 & -1.64 & 1.64 & 0.70 & 0.05 & 0.96 & 0.41 & -0.01 & -0.20 & 2.92 & 1 \\
\hline 18 & Hoshairpur & 45722 & -10694 & -1.38 & 85 & -62 & -1.20 & 1.20 & 0.73 & 0.08 & 1.74 & 0.40 & -0.03 & -0.59 & 0.96 & 6 \\
\hline 19 & Nawanshehar & 56807 & 391 & 0.05 & 175 & 28 & 0.55 & -0.55 & 0.71 & 0.06 & 1.33 & 0.41 & -0.01 & -0.25 & 0.57 & 7 \\
\hline \multirow[t]{3}{*}{20} & Ropar & 44593 & -11823 & -1.53 & 93 & -54 & -1.04 & 1.04 & 0.70 & 0.05 & 0.98 & 0.42 & 0.00 & -0.03 & 0.47 & 8 \\
\hline & $\overline{\mathrm{x}}_{*}^{*}$ & 56415.95 & & & 147 & & & & 0.65 & & & 0.42 & & & & \\
\hline & SDII & 7735.64 & & & 51 & & & & 0.05 & & & 0.04 & & & & \\
\hline
\end{tabular}

Notes:

$159 \dagger \mathrm{X}=\mathrm{A}$ set of actual values of the variable considered.

$160 \ddagger \bar{x}=$ Mean of $X$.

$161 \S$ Groundwater Development (\%) had an inverse relationship with agricultural sustainability, thus, the Figures were 162 multiplied with -1 to get their respective inverse values.

163 II $\mathrm{SD}=$ Standard Deviation

164 Source: Singh and Benbi (2016)

To calculate the FII, the values of each of the indicators for each of the 20 districts were normalised (X- $\bar{x}) / \mathrm{SD})$, and

167 then all the realised values were added to obtain a composite score for each of the districts using the formula devised

$$
F I=\sum_{i=1}^{n} \frac{\mathrm{X}-\overline{\mathrm{x}}}{\mathrm{SD}}
$$

170 where 
$171 \mathrm{X}=\mathrm{a}$ set of actual values of the variable considered,

$172 \quad \bar{x}=$ Mean of $X$,

$173 \mathrm{SD}=$ Standard Deviation of $\mathrm{X}$,

$174 \mathrm{n}=$ Number of variables.

175 In relation to the 20 districts, Muktsar had the highest FII scoring 2.92 whereas Tarantaran was ranked $20^{\text {th }}$ with the

176 lowest FII of -3.90 , where a higher score represents a greater intensity. All 20 districts were divided into three groups

177 based on their overall ranking. The first group had six districts having an FII between 2.92 and 0.92 whereas the

178 second group was formed of eight districts with an FII between 0.57 and -1.12. The third group was formed from the

179 remainder six districts having an FII between -1.37 and -3.90 (Table 2). Then, three districts were chosen: one from

180 each of the three groups considering their relative ranking within the group in combination with agro-climatic

181 condition. Gurdaspur, Barnala and Ferozepur (Fig. 1), which represented the sub-mountainous, central and south-

182 western agro-climatic zones of Punjab, respectively were selected for the field survey (Singh and Benbi 2016).

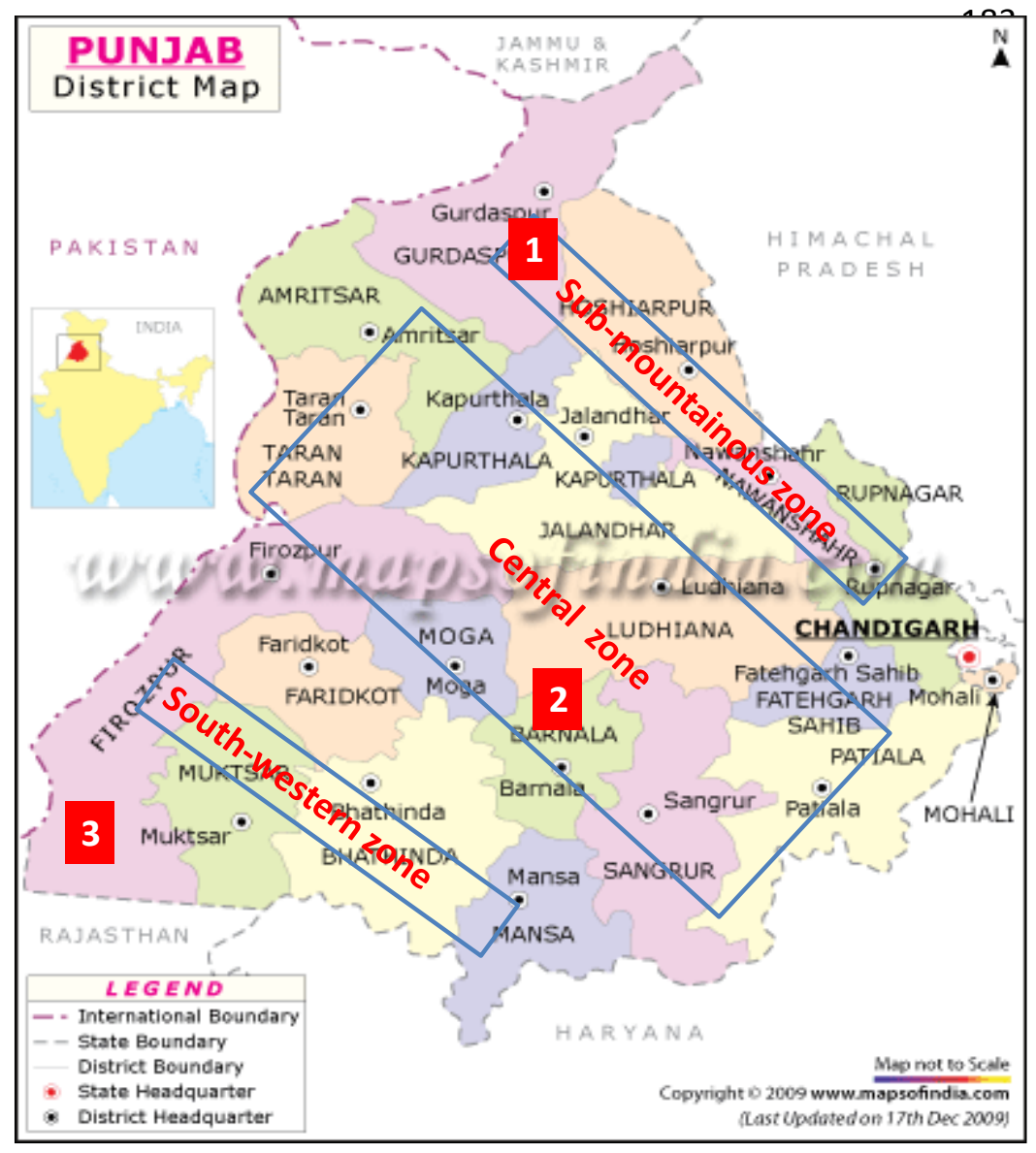

Fig. 1 District map of Punjab showing research regions chosen for field survey 
Groundwater Resources in the Indian Punjab

Source: Singh and Benbi (2016)

197 To maintain consistency, the same sampling technique and sustainability indicators were used to select blocks. 198 However, due to unavailability of block level production data, the other three indicators of agricultural sustainability 199 were used. One block (a cluster of villages within a district) from each district was selected. Three blocks, Gurdaspur, 200 Sehna and Fazilika were selected in Gurdaspur, Barnala and Ferozepur districts respectively. Then, owing to 201 unavailability of secondary data on sustainability indicators at village level, the extension workers of the block 202 concerned were consulted to identify two divergent (i.e., one relatively more and one relatively less intensively 203 farmed) villages from each of the selected blocks.

204 As used by Singh and Benbi (2016), after identifying the villages, 20 farmers were selected from each of the six 205 villages using a stratified sampling technique. In total, 120 farmers were selected across three districts/blocks. The 206 selected group of farmers in each village represented the range of landholding sizes, i.e., small, medium and large, of 207 the village concerned. Taking into consideration the current landholding distribution in Punjab ${ }^{13}, 30 \%$ small, $60 \%$ 208 medium and 10\% large farmers were selected in each of the villages.

209 A semi-structured interview schedule was used to collect a range of socio economic data. The interview schedule was 210 translated into Punjabi, the local language of Punjab, to minimise the communication gaps during the field survey. To 211 ensure anonymity, a unique code was allotted to each of the respondents. All the interviews were digitally recorded 212 with the consent of the interviewee concerned. The Statistical Package for Social Sciences (SPSS) was used to realize 213 all the descriptive tables and analyze the data. For regressions, a general ANOVA model, which adjusts the predicted 214 means of dependent variable with respect to each independent variable for the effect of all the independent factors, was used. Correlation values across all independent variables used in the regressions were examined using bivariate 216 corrleation and Chi-sqaure tests and no variable showed a siginificant association with each other.

13 As per the latest available data on landholding distribution in Punjab (GoP 2012), about 32\%, 60\% and 8\% of farmers are marked as small (less than $2 \mathrm{ha}$ ), medium (2-10 ha) and large (more than $10 \mathrm{ha}$ ) landholders. 


\subsection{Farmers' profiles, cropping patterns and tubewell density}

The average size of landholding cultivated was 4.8 ha (Min $=0.4$ ha, Max $=36$ ha, $S D=5.45$ ). About four-fifth of the total 120 farmers surveyed were above 36 years of age, of which, one-third were more than 55 -year old. Only $20 \%$ of farmers were younger than 36 years of age. Levels of technology were relatively high with $75 \%$ and $95 \%$ of the farmers having a tractor and a tube well respectively. In terms of their educational attainments, about $90 \%$ of the farmers were senior secondary school ( $12 \mathrm{Grade})$ literate, of which $11 \%$ had graduated while the remaining $10 \%$ were illiterate i.e. unable to read and write. About $91 \%$ of the land area was cultivated by the medium and large holders, who accounted for $70 \%$ of the farmer population whereas the smallholders (cultivating less than 2 ha), who comprised of 30\% of the farmer population, were left with only 9\% of the total land area (Singh and Benbi 2016).

All 120 farmers surveyed across the three agro-climatic regions of Punjab grew at least two crops in a given year. Thus, the average cropping intensity was over $200 \%$ with significant intra-zone variations $\left(X^{2}(4,120)=16.1 p<.01\right)$. Farmers in the central (Barnala) and south-western (Ferozpur) zones had a combined average cropping intensity of $202 \%$. In other words, $82 \%$ of farmers ${ }^{14}$ cultivated their land more than twice a year whereas the remaining $18 \%$ of them grew at least two crops a year. An average crop diversity (CDI) across all three zones was $0.61^{15}$ (Min $=0.50$, Max $=0.75$ ) with no significant regional variations. However, cropping patterns in the Kharif season were slightly more diverse than in the Rabi season. Wheat and rice occupied about $83 \%$ and $73 \%$ of the net sown area in the Rabi and Kharif seasons respectively. Overall, the current cropping patterns can be termed as highly intensive with limited crop diversity (Singh and Benbi 2016).

Of the 120 farmers interviewed, $114^{16}$ farmers had 211 tubewells in total (1.8 tube wells per farmer; one tube well per 2.7 ha), out of which $82 \%$ were electric-operated submersible pumps specially designed to extract water from deeper

14 Punjab can be divided into three agro-climatic zones i.e. sub-mountainous, central and south-western zones covering $18 \%, 51 \%$ and $31 \%$ of the land area respectively (Singh 2011).

15 Crop diversity for each farmer was calculated using the Hirschman-Herfindahl Index (HHI) explained in the Material and Methods section.

16 Six farmers did not own tube wells and were asked to record the groundwater level estimates of their neighboring tube well. Further, as about $44 \%$ of the farmers had more than one tube well, data was used for the first tube well they reported. 
levels. Further, $83 \%$ of the total tubewells and $86 \%$ of the total electric-operated tubewells were situated on medium and large holdings. In contrast, half of the smallholders irrigated their farms with diesel engine-based pumps, thus, not receiving any benefits from the subsidized power provided to those using electricity-run tubewells.

\subsection{Current groundwater level}

242 The average level of groundwater was 14 metres $(S D=8.30, N=120)$ ranging between 1 and 30 metre across all 120

243 farms spread across all three agro-climatic zones. It was the deepest in Barnala (Mean $=22$ metre, $S D=5.11, N=40)$

244 followed by Gurdaspur (Mean $=12$ metre, $S D=6.21, N=40)$ and Ferozpur (Mean $=7$ metre, $S D=4.43, N=40)$. In

245 the central zone (Barnala) where all the 40 sampled farmers were withdrawing from deeper than 11 metres, of which,

$24655 \%$ were extracting beyond 20 metres (Table 3). In contrast, only $7 \%$ of the farmers in the sub-mountainous

247 (Gurdaspur) zone had groundwater deeper than 20 metres whereas all the farmers in the south-western zone were able

248 to access water within 20 metres. Across all zones, for $72 \%$ of the farmers, groundwater was deeper than 11 metres,

$24912 \%$ had it between 4 and 10 metres, which can be classed as "a normal level" ${ }^{17}$. Only $16 \%$ of the farmers actually

250 reported a problem with water-logging. The reason for water-logging ${ }^{18}$ is quite localized and based on agro-climatic 251 conditions.

Table 3 Average Groundwater Level (AGL in metres) across all three zones reported by farmers

254 Source: Survey data

\begin{tabular}{|l|c|c|c|c|}
\hline \multirow{2}{*}{ Water table level } & \multicolumn{3}{c|}{ Number of farmers (\%) } & \multirow{2}{*}{ Overall } \\
\cline { 2 - 4 } & Gurdaspur & Barnala & Ferozpur & \\
\hline$\leq 3$ metres & 8 & & 42 & 16 \\
\hline $4-10$ metres & 18 & & 18 & 12 \\
\hline $11-20$ metres & 67 & 45 & 40 & 51 \\
\hline$>20$ metres & 7 & 55 & & 21 \\
\hline \multicolumn{1}{c|}{$n$} & 40 & 40 & 40 & 120 \\
\hline
\end{tabular}

17 According to the Ministry of Water Resources (MWR, 1991), the area is treated as safe from water logging if the groundwater level is 3 metre below the land surface while an ordinary diesel engine operated tube well can pump out the groundwater from up to 10 metres. Thus, between 4 and 10 metres was considered as "a normal level".

18 According to the Planning Commission of India (2013), "an area is said to be waterlogged when the groundwater level rises to such an extent that the soil pores in the root zone of a crop become saturated, resulting in restriction of normal circulation of air, decline in the level of oxygen and increase in the level of carbon dioxide. The harmful depth of groundwater would depend on the type of crop, type of soil and quality of water." 
Analyzing the long-term trends in groundwater depth (Fig. 2), fifty-eight per cent of the farmers reported a fall of 3 15 metres between 2000 and 2010, of which, 30\% had a groundwater fall of 6-15 metres. Region-wise, the 257 groundwater fall was found to be the greatest in the central zone (Barnala) where $66 \%$ of the farmers reported a decline 258 of 6-15 metres and another $26 \%$ farmers suggested a depletion of more than 15 metres.

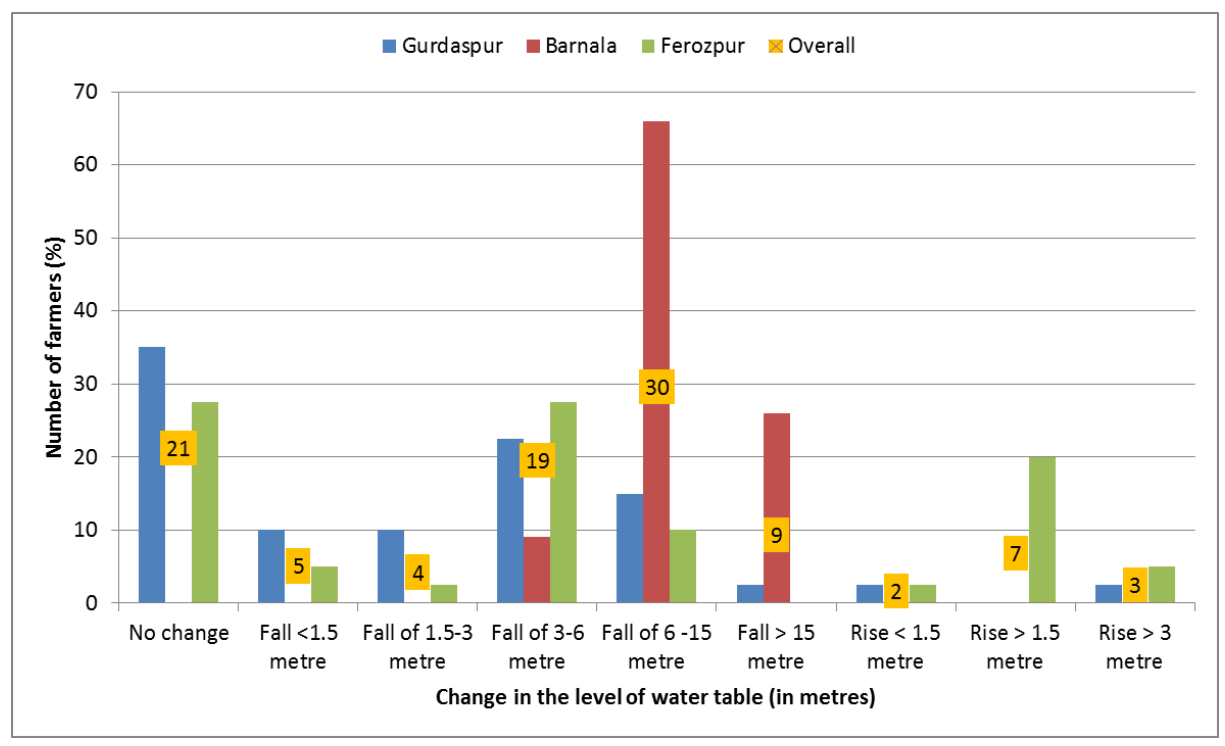

Fig. 2 Change in the groundwater level (in metres) experienced by farmers across different agro-climatic zones between 2000 and 2010

On the other hand, in the sub-mountainous zone (Gurdaspur), only $20 \%$ of the farmers experienced groundwater depletion of greater than 3 metres. In the south-western zone (Ferozpur), only $10 \%$ of the farmers experienced a fall in the groundwater level of between 6 and 15 metres, while the remaining $90 \%$ of the farmers saw either a fall of between 3 and 6 metres or a rise. Note that the groundwater of this region is often not fit for irrigation; it is brackish and needs to be used in combination with surface water. Overall, the data suggests that groundwater resources in

267 Punjab are continuously depleting, especially in the central region where the depletion rate between 2000 and 2010 had been relatively very high.

\subsection{Socio-economic factors affecting the groundwater depth}

In addition to agro-climatic conditions and regional topography, groundwater level (effect) is affected by a range of 271 socio-economic (farmer-and farm-specific) factors (cause). Table 4 shows that the groundwater depth varied 
272 significantly with respect to agro-climatic region, farmers' educational level, and crop diversity whereas the other

273 factors e.g. size of landholding, farmer age, tractor ownership, cropping intensity, and farmers' connectivity to

274 extension had no significant association with the groundwater level.

275 Table 4 A general ANOVA model showing the level of variation in the Average Groundwater Level (AGL in metres) with respect to various socio-economic factors

\begin{tabular}{|c|c|c|c|c|c|}
\hline \multicolumn{6}{|c|}{ Tests of Between-Subjects Effects } \\
\hline \multicolumn{6}{|c|}{ Dependent Variable: Average Groundwater Level (in metres) } \\
\hline Source & $\begin{array}{l}\text { Type III Sum of } \\
\text { Squares }\end{array}$ & df & $\begin{array}{l}\text { Mean } \\
\text { Square }\end{array}$ & $\mathbf{F}$ & Sig. \\
\hline Corrected Model & $5449.642^{\mathrm{a}}$ & 14 & 389.260 & 14.901 & .000 \\
\hline Intercept & 3142.387 & 1 & 3142.387 & 120.290 & .000 \\
\hline Agro-climatic region & 3490.463 & 2 & 1745.231 & 66.807 & .000 \\
\hline Landholding size & 34.768 & 2 & 17.384 & .665 & .516 \\
\hline Farmer age & 10.887 & 2 & 5.444 & .208 & .812 \\
\hline Farmer education & 183.000 & 2 & 91.500 & 3.503 & .034 \\
\hline Tractor ownership & 15.404 & 1 & 15.404 & .590 & .444 \\
\hline Cropping intensity & 62.120 & 2 & 31.060 & 1.189 & .309 \\
\hline Crop diversity & 251.723 & 2 & 125.862 & 4.818 & .010 \\
\hline Connectivity to extension & 5.974 & 1 & 5.974 & .229 & .633 \\
\hline Error & 2742.949 & 105 & 26.123 & & \\
\hline Total & 31239.000 & 120 & & & \\
\hline Corrected Total & 8192.592 & 119 & & & \\
\hline \multicolumn{6}{|c|}{ a. $\mathrm{R}$ Squared $=.665($ Adjusted $\mathrm{R}$ Squared $=.621)$} \\
\hline
\end{tabular}

Source: Model results

279 The groundwater depth varied significantly $(F(2,105)=66.807, p<.001))$ across agro-climatic regions with the 280 deepest being Barnala, followed by Gurdaspur and the highest being Ferozpur. These Figures are in agreement with 281 the state-level estimates (Fig. 3). The post-hoc comparisons suggested that the groundwater level was significantly 282 deeper in Barnala (Mean difference $=10$ metres, $S E=1.143, p<.001)$ than in Gurdaspur as well as $($ Mean difference $283=15$ metres, $S E=1.143, p<.001)$ in Ferozpur. Further, it was also significantly deeper in Gurdaspur (Mean difference $284=5$ metres, $S E=1.143, p<.001)$ than in Ferozpur. Most farmers in Barnala were facing low groundwater levels 285 whereas, in Gurdaspur and Ferozpur, some of them reported waterlogging resulting in damaged crops. Further, the 286 standard error Figures suggest wide variations within the regions as well. 


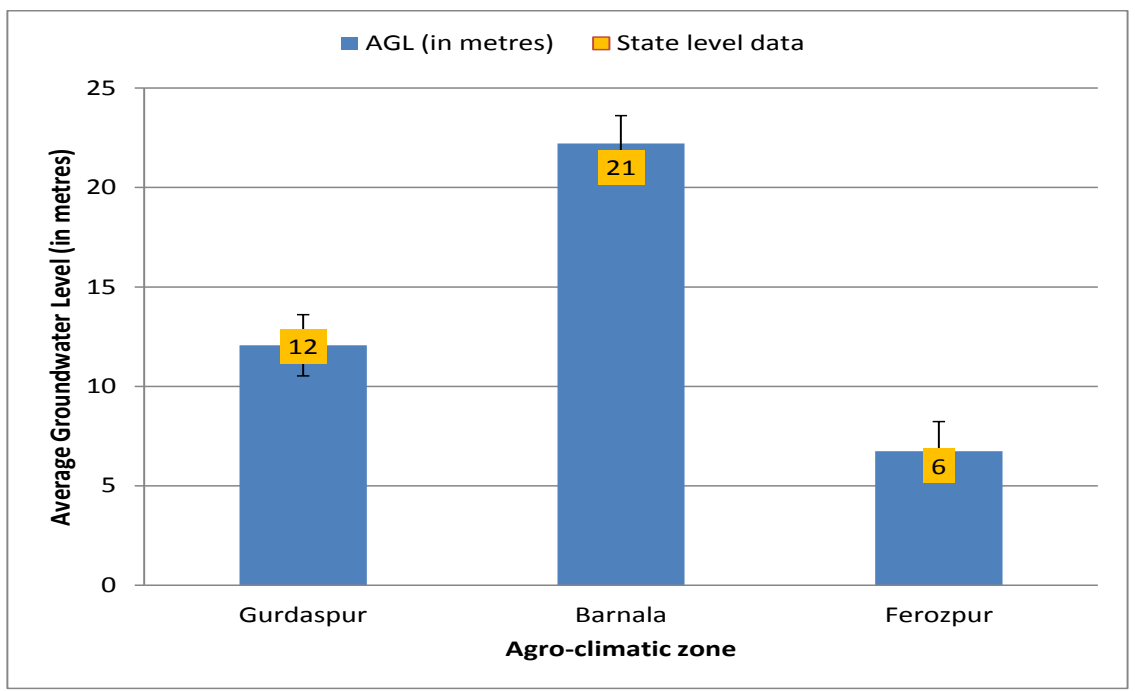

Fig. 3 Average Groundwater Level (AGL in metres) across all three agro-climatic zones

Notes: The State level data are the average of minimum and maximum levels of groundwater in June 2010

291 Source: Survey data; GoP (2012)

292 Further, the association between farmer education and groundwater level was significant $(F(2,105)=3.503, p<.05))$.

293 Fig. 4 suggests that both the illiterate and graduate farmers, although constituting only $22 \%$ of the total farmer 294 population, were withdrawing the groundwater from deeper levels (15 metres) than other farmers (12 metres).

295 However, the post-hoc comparisons suggest that illiterate and graduate farmers had a significantly deeper levels of groundwater (Mean difference $=3$ metres, $S E=1.465, p<.01$ ) than other farmers who made up $78 \%$ of the total.

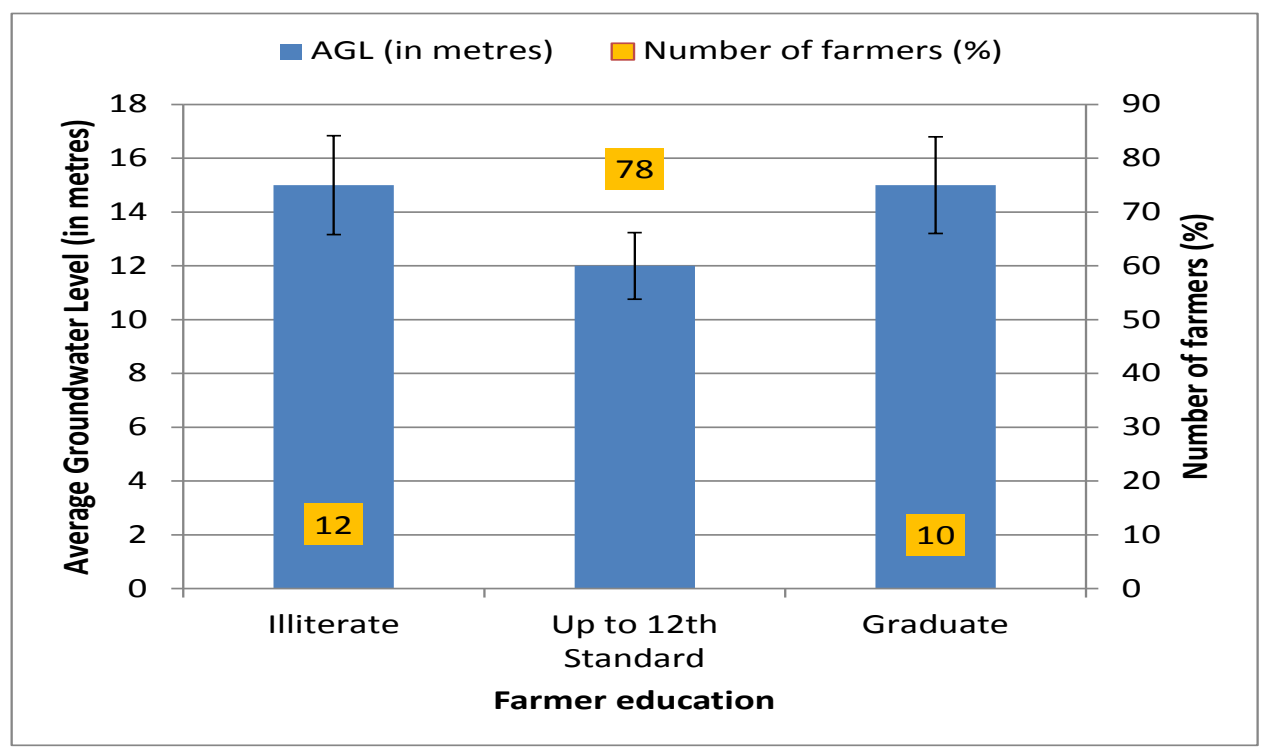

Fig. 4 Average Groundwater Level (AGL in metres) with respect to educational attainments among farmers 
Groundwater Resources in the Indian Punjab

Source: Survey data

Results suggest a direct relationship between crop diversity and groundwater depth. For instance, farmers with a higher crop diversity $(>0.70)$ had significantly $(F(1,105)=4.818, p<.05)$ shallower groundwater depth $(10$ metres $)$ compared with those who chose to concentrate on fewer crops (14-16 metres) (Fig. 5). This specialized group (with crop diversity below 0.70 ) accounted for $93 \%$ of the total farmer population. Thus, the mono-cropping could be one of the reasons for the depletion of sub-soil water in Punjab. The post-hoc comparisons suggest that farmers with crop diversity index of more than 0.70 had significantly (Mean difference $=5$ metres, $S E=1.946, p<.05$ ) shallower groundwater levels than those whose level of diversity was less than 0.60 . However, farmers having diversity level of 0.60-0.70 and more than 0.70 were withdrawing the groundwater from similar levels.

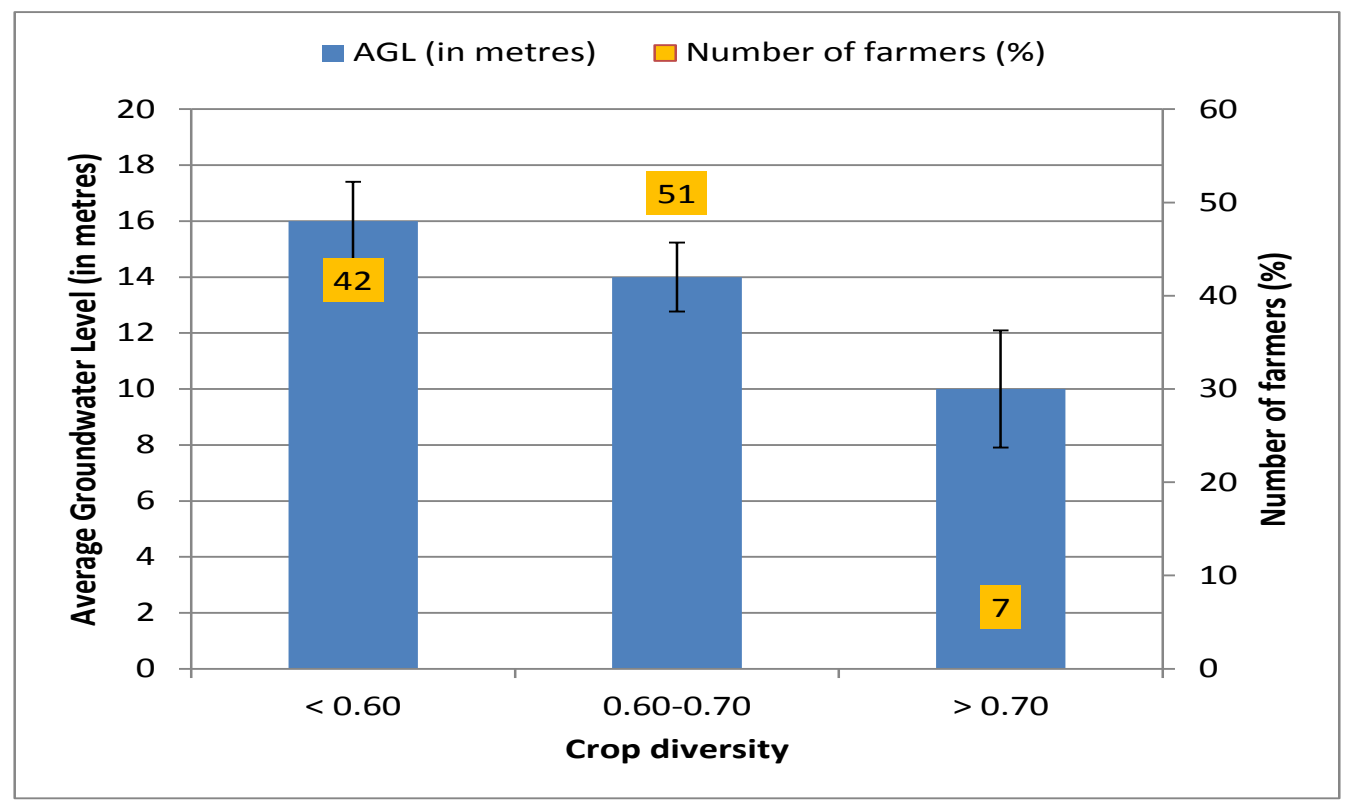

Fig. 5 Average Groundwater Level (AGL in metres) with respect to varying levels of crop diversity

311 As the level of groundwater across Punjab varied mainly due to agro-climatic conditions, statistical comparisons were 312 also made within each of the three regions. In Gurdaspur, the groundwater level varied significantly with respect to 313 farmer education $(F(2,28)=3.694, p=.05)$, cropping intensity $(F(1,28)=7.484, p=.05)$, and crop diversity $(F(2$, $31428)=4.196, p=.05)$ whereas, in Barnala and Ferozpur, it had a significant association with farmer education $(F(2$, $28)=4.740, p=.05)$ and crop diversity $(F(2,28)=4.641, p=.05)$ respectively (Table 5). 
Table 5 A general ANOVA model showing a district-wise level of variation in the Average Groundwater Level

(AGL in metres) with respect to various socio-economic factors

\begin{tabular}{|c|c|c|c|c|c|c|}
\hline \multicolumn{7}{|c|}{ Tests of Between-Subjects Effects } \\
\hline \multicolumn{7}{|c|}{ Dependent Variable: Average Groundwater Level (in metres) in Gurdaspur, Barnala and Ferozpur } \\
\hline \multirow[b]{2}{*}{ Source } & \multicolumn{2}{|c|}{ Gurdaspur } & \multicolumn{2}{|c|}{ Barnala } & \multicolumn{2}{|c|}{ Ferozpur } \\
\hline & $\mathbf{F}$ & Sig. & $\mathbf{F}$ & Sig. & $\mathbf{F}$ & Sig. \\
\hline Corrected Model & 2.008 & .067 & 1.258 & .298 & 1.994 & .067 \\
\hline Intercept & 24.283 & .000 & 104.290 & .000 & 5.965 & .021 \\
\hline Landholding size & 2.355 & .113 & .196 & .823 & .261 & .772 \\
\hline Farmer age & .374 & .691 & .060 & .942 & .573 & .571 \\
\hline Farmer education & 3.694 & .038 & 4.740 & .017 & .873 & .429 \\
\hline Tractor ownership & 1.515 & .229 & .217 & .645 & .094 & .761 \\
\hline Cropping intensity & 7.484 & .011 & .577 & .454 & .810 & .455 \\
\hline Crop diversity & 4.196 & .025 & .401 & .673 & 4.641 & .019 \\
\hline Connectivity to extension & .286 & .597 & .689 & .414 & .051 & .823 \\
\hline Error & 841.254 & 28 & 682.410 & 28 & 405.463 & 27 \\
\hline Total & 7337.000 & 40 & 21135.000 & 40 & 2767.000 & 40 \\
\hline Corrected Total & 1504.775 & 39 & 1019.775 & 39 & 764.775 & 39 \\
\hline \multicolumn{7}{|c|}{ R Squared: Gurdaspur=.441; Barnala=.331; Ferozpur=.470 (Adjusted R Squared: Gurdaspur=.221; Barnala=.068; Ferozpur=.234) } \\
\hline
\end{tabular}

319 Source: Model results

320 In relation to farmer education (Fig. 6), graduate farmers in Gurdaspur and Barnala were extracting water from deeper 321 levels (19 and 27 metres) than the school-educated farmers (11 and 19 metres) who accounted for $82 \%$ and $73 \%$ of 322 the total farmer population respectively. However, illiterate farmers in Gurdaspur had shallower groundwater levels 323 (4 metres) but at the same time, in Barnala, they experienced much deeper levels of groundwater (26 metres) than the 324 majority of farmers (19 metres). Post-hoc comparisons showed a significant groundwater level variation (Mean 325 difference $=5$ metres, $S E=1.884, p<.05$ ) between illiterate and other farmers in Barnala while, in Gurdaspur, they did not suggest a significant variation with respect to farmer education. 


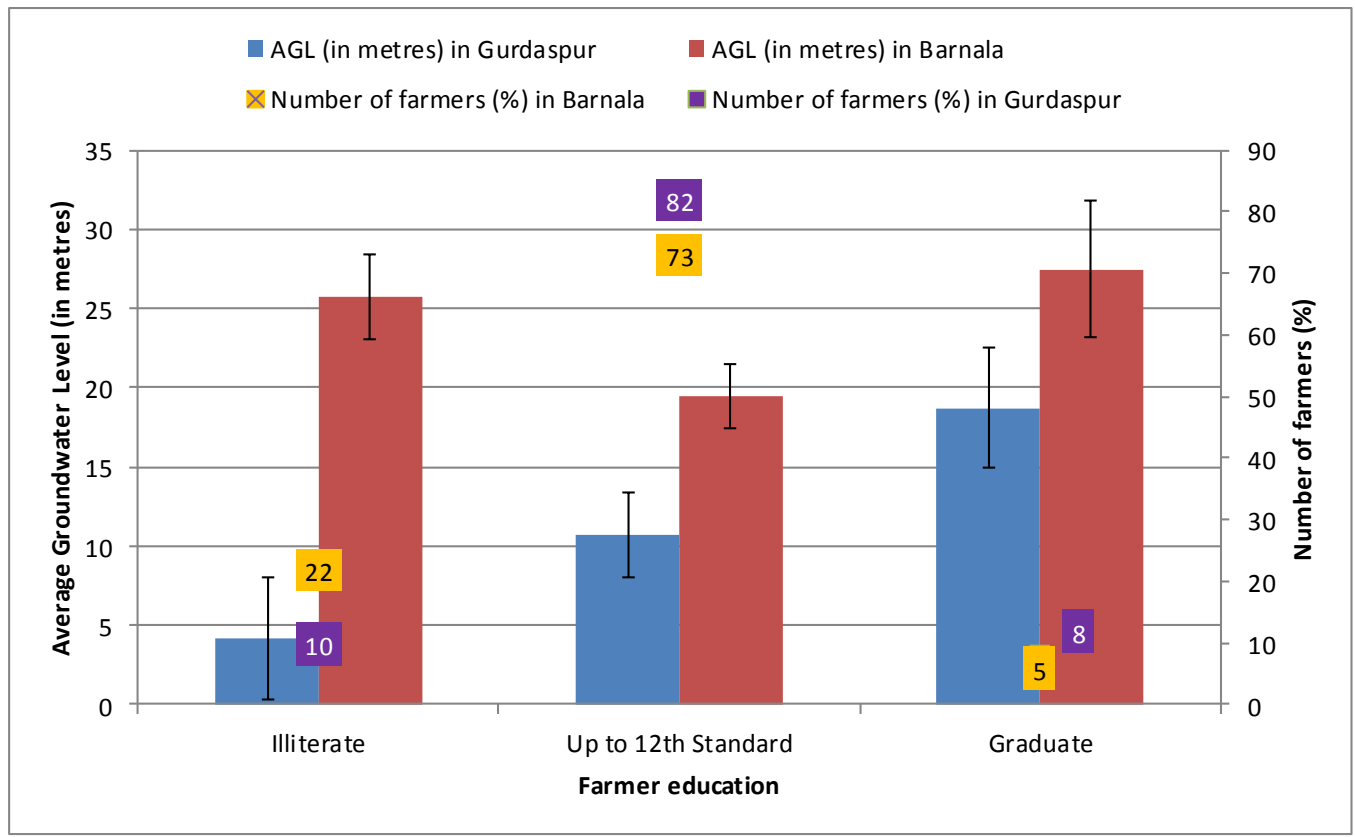

Fig. 6 Average Groundwater Level (AGL in metres) with respect to farmer education in Gurdaspur and Barnala

Compared with the respective overall averages, school-passed farmers in Gurdaspur and Barnala had much shallower water level (11 and 19 metre) than the respective overall averages (12 and 22 metres) while the graduate farmers in both regions had deeper groundwater levels (19 and 27 metres) than the respective overall averages. Overall, farmer education in Gurdaspur presents a clear association (direct relationship) with groundwater level whereas in Barnala, this relationship provides no trend.

In relation to cropping intensity (Fig. 7), farmers growing less than two crops in a year (200\%) in Gurdaspur had deeper groundwater (16 metres) than those who grew just two crops (6 metre). However, no farmer here grew more than two crops in a given year. Fig. 7 illustrates clearly that farmers concentrating on fewer crops (less than 0.60) both in Gurdaspur (sub-mountainous) and Ferozpur (south-western zones) were withdrawing groundwater from significantly deeper levels (16 and 10 meters) compared with (4 meters) those who decided to grow a variety of crops (more than 0.70 ) although the proportionate number of such farmers in both the regions was only $8 \%$. Other farmers,

341 who had a crop diversity between 0.60 and 0.70 , had groundwater levels of 14 and 5 metres and such farmers constituted about half of the total farmer population in both the regions. 


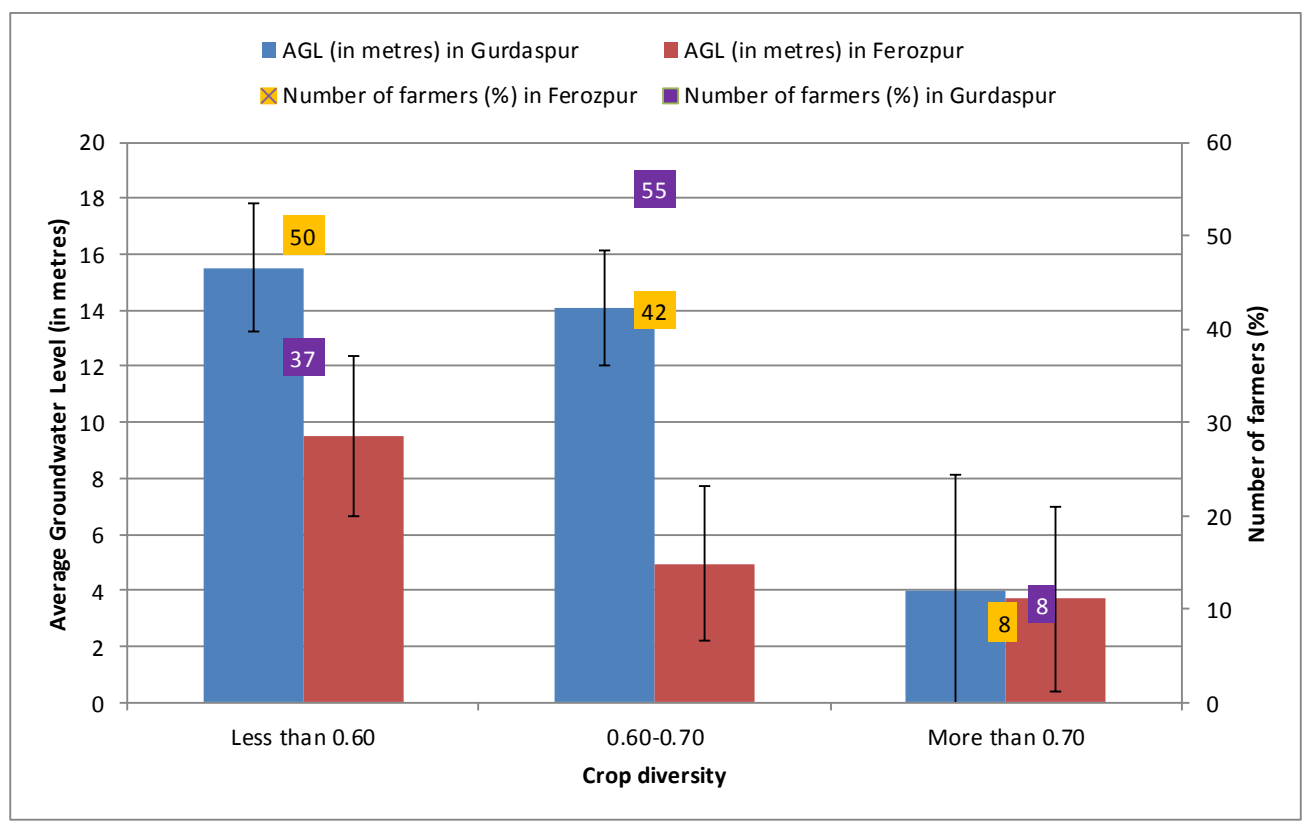

Fig. 7 Average Groundwater Level (AGL in metres) with respect to the level of crop diversity in Gurdaspur and Ferozpur

Source: Survey data

347 The post-hoc comparisons suggested that farmers in Ferozpur with a lower crop diversity (less than 0.60) had extract 348 from significantly deeper than those who had a crop diversity of 0.60-0.70 (Mean difference $=4$ metres, $S E=1.278$, $p<.01$ ) and more than 0.70 (Mean difference $=7$ metres, $S E=2.399, p<.05$ ). However, groundwater level did not vary significantly between farmers having a crop diversity of $0.60-0.70$, and beyond 0.70 . For Gurdaspur, these variations were insignifcant.

352 Farmers were asked to comment on some policy related questions, particularly on crop diversification and free electricity to the farm sector. Seventy percent of the farmers felt that lower crop diversity due to an expansion of area under rice has led to a mining of sub-soil water resources in Punjab although only one-third of them would consider stopping rice cultivation. Probably, that is why no farmer suggested stopping of free electricity to farm sector as it helps them bring irrigation costs down to almost zero. However, $82 \%$ farmers, who responded to these questions, were 357 ready to pay for electricity if government ensures a regular supply. One-fifth of the farmers would consider delaying 358 rice planting further until $30^{\text {th }}$ June (which is currently $15^{\text {th }}$ June). 


\section{Discussion}

Groundwater depletion in Punjab is a general phenomenon although more serious in the central zone where the average groundwater depth was reported as 22 metres compared with 12 metres in sub-mountainous (Gurdaspur) and 7 metres in south-western (Ferozpur) zone. Further, a wider variation within the zones suggests that not only the agro-climatic conditions but a range of other factors also affect the withdrawal of groundwater resources.

364 Two-third of the farmers witnessed an annual fall ranging from between $50 \mathrm{~cm}$ and 1.5 metres. These findings are 365 almost similar to the findings of CGWB (2012) using data from 361 monitored wells across Punjab. In the central 366 zone, where the problem of groundwater depletion is more severe than the other regions, only $5 \%$ of the farmers were 367 accessing groundwater at a depth shallower than 11 metres. More than $65 \%$ of the sampled farmers reported that the groundwater level had declined more than $60 \mathrm{~cm}$ annually and another $26 \%$ found this depletion beyond $1.5 \mathrm{~m}$.

369 However, the groundwater depletion in the sub-mountainous region is not currently that serious. However, 370 continuously expanding rice cultivation and shrinking canal irrigation base in the south-western region, which is 371 traditionally known as the cotton belt of Punjab, could create further implications for the ecological balance of this 372 region. Thus, both the existing literature (CGWB 2012; Singh 2012a) and results of this study are in agreement and 373 suggest that Punjab is facing a serious crisis regarding its groundwater resources, creating a range of long-term implications for the next generation.

In terms of major drivers of change in the groundwater level, besides agro-climatic conditions, farmer education and low crop diversity had a significant association with it. However, the relationship between farmer education and

377 groundwater level does not provide a clear picture as both highly educated (graduate) and illiterate farmers had deeper 378 groundwater levels than other farmers. Therefore, farmer education cannot be directly linked to groundwater depletion 379 in Punjab. regions as well as within the regions (Gurdaspur and Ferozpur), suggests that if water conservation is to increase, the culture of mono-cropping focused around rice cultivation needs to be discouraged or more sustainable ways of rice cultivation are to be found and disseminated to farmers. However, despite State government's efforts to increase crop diversity, the area under wheat and rice is constantly expanding (PSFC 2013). In fact, wheat and rice make the best 
crop combination in terms of economic returns and productivity related risks (Shergill, 2013; Sarkar and Das, 2014).

386 Further, based on the instability indices calculated for major crops in Punjab from 1970-71 to 2006-07; instability

387 indices of wheat and rice were 0.06 and 0.08 respectively, while for cotton, sugarcane and maize, the major crops

388 suggested by the Punjab government in its recent policy draft (PSFC 2013), the respective Figures were 0.27, 0.07 and 0.18 (Sidhu and Vatta n.d.). Therefore, farmers in Punjab lack a set of alternative crops which not only could compete with wheat and rice in terms of economic returns and productivity related risks but also consume less water and allow seepage for groundwater recharging. In fact, it is a clarion call for the agricultural researcher, scientists and policy makers to provide a sustainable crop-mix to farmers.

However, here, it is essential to understand that the problem is the over-withdrawal of groundwater not rice cultivation per se. Therefore, technical diversification could be one of the potential solutions rather than compelling farmers to diversify in the absence of economically viable alternative crops to wheat and rice. If farmers are educated to cultivate rice using more sustainable farming techniques in addition to widely establishing more efficient rain harvesting techniques, both the economic and environmental goals of agricultural sustainability could possibly be achieved. Here,

398 it is to be noted that various water saving techniques except SRI (System of Rice Intensification) and direct seeding 399 cannot be effectively used in rice cultivation.

400 While looking at a continuous lowering of crop diversity in Punjab, it could be a manifestation of provision of free 401 electricity to farm sector as the area under rice increased steeply in 1997 when the state government introduced this policy (Sarkar and Das 2014). Thus, it could be a major catalyst which encourages farmers to grow wheat and rice 403 and discourages them from using water conservation technologies despite heavy government subsidies. However, 404 Singh (2012a) argued that even if the electricity subsidy were withdrawn, wheat and rice would still remain the best crop mix in terms of net economic returns. Further, with the current productivity levels and pricing mechanism in the 406 state, saving electricity through crop diversification is not economically feasible as it will bring monetary losses to 407 farmers and, eventually they will return to wheat-rice rotation unless they don't get financial incentives from the government. It is estimated that the amount of financial support required to make a shift in the current cropping pattern, especially shifting of one-fourth of the area under rice to maize, is much higher than the total electricity subsidy saved 410 in the next 10 years alongside continuous groundwater depletion (Sarkar and Das 2014). Thus, the past and the present 
411 crop diversification plans are not economically feasible without a robust financial backup plan from the central

412 government as the state government is already facing financial straits ${ }^{19}$.

413 In terms of association of groundwater level with socio-economic factors within the agro-climatic regions, graduate

414 farmers in Gurdaspur and Barnala had been over-exploiting the groundwater resources more randomly than the poorly-

415 educated farmers. However, at the same time, poorly-educated farmers in Barnala were withdrawing water from

416 shallower levels than the illiterate and graduate farmers. Although the results don't provide any clearer relationship

417 between farmer education and groundwater resources, it provides ample opportunities to the State extension agencies

418 (Department of Agriculture, Punjab and Punjab Agricultural University Ludhiana) to educate farmers about the 419 ecological implications of a declining groundwater level and trying to convince them to adopt more sustainable

420 farming techniques that save water without reducing their net profitability. This involves some challenges as only a

421 limited number of farmers are currently connected to public extension services in India (NSSO 2005) and it is also

422 not certain whether the currently employed public extensionists have an updated and correct knowledge and the

423 required skill set to deal with sustainable agriculture related issues.

\section{5. Conclusions}

425 This research suggests that groundwater depletion in Punjab, in general, and in the central zone, in particular, is a 426 serious concern in relation to the environmental sustainability of farm enterprises in Punjab. Both the results of this 427 study and literature suggest that, in the central zone, the groundwater level on $92 \%$ of the farms had depleted by more than 0.60 metres annually between 2000 and 2010. While, the current state of groundwater resources in the other two 429 regions is not too serious and manageable for the time being. However, if the existing policy framework for groundwater resources in the state, which allows the state government to release 0.11 million more connections to

19 The militant movement (1980-1992) aimed at creating a separate Independent State for Sikhs along with other economic and political issues jeopardized Punjab's economy. Punjab has been borrowing continuously from national and international financial institutions including the Union government since the mid-1980s (Kaur 2010). Punjab's present debt is Rs 7,75,850 million (GoP 2012). 
431 farmers putting much pressure not only on the groundwater resources but also burdening the state exchequer, 432 continues, Punjab can end up losing much of its groundwater resources.

433 Further, crop diversity emerged as the main driver of change in the groundwater level not only across regions but also within the regions except the central zone (Barnala) where the crop diversity was the lowest and had very little 435 variation within the region. Education among farmers across regions as well as in the sub-mountainous (Gurdaspur) and the south-western (Ferozpur) zones had an unclear relationship with groundwater levels.

437 Given that the groundwater depletion in Punjab is a complex problem with a range of policy, economic, attitudinal, 438 social and political dimensions, a multidimensional approach will be required to overcome further over-abstraction. The following measures could form the basis of such an approach:

1. As the results suggest a significant association between the level of crop diversity and groundwater resources, and the literature hits at the failure of past crop diversification policies in Punjab, future crop diversification policies and programs need to be more practical and pragmatic bearing in mind the agro-climatic conditions and market potential of different agro-climatic regions. It will need a close synchronization of policy, research and extension agencies so that whatever is planned by the policy makers and endorsed by the researchers, the same should be disseminated to farmers with no communication gap. Crop-diversification plans should address the productivity and marketingrelated risks so that farmers feel convinced and can have enough confidence to experiment with alterative cropping patterns.

2. Policy makers should be aware that wheat-rice makes the best crop combination in terms of lower productivity risks and higher economic returns, therefore, the future policies can also target technical diversification in terms of reducing water use in wheat-rice cultivation. As the adoption of water conservation technologies is low in Punjab, government could initiate more pragmatic programs to disseminate these technologies. However, researchers should evaluate the success rate and economic rate of return of all the technologies before prescribing them to farmer.

3. Farmers can sow a third (preferably non-irrigated) crop in between wheat and rice, i.e. mungbean (a legume), during May-June, as the cropping intensity did not show any negative effect on the groundwater resources and soil health. It will not only bring higher returns to farmers but also 
Groundwater Resources in the Indian Punjab

improve soil health. Additionally, scientists have to provide short-duration crop varieties to facilitate cultivation of three crops in a year and extensionists might need to update their knowledge on new crops and their cultivation methods as they have specialized around wheat-rice production systems for decades.

4. "The Punjab Preservation of Sub Soil Water Act, 2009" which currently forbids farmers to transplant rice before $15^{\text {th }}$ June, needs reviewing as one-fifth of the farmers surveyed agreed to delay sowing of rice by another two weeks. Additionally, as monsoons reach Punjab by the first or second week of July, June $15^{\text {th }}$ could be extended to June $30^{\text {th }}$ that would help save water used for rice cultivation without compromising the productivity levels.

\section{Acknowledgements}

We are indebted to the School of Agriculture, Policy and Development at the University of Reading and Punjab Agricultural University, Ludhiana, India for their help in conducting this study. We thank our colleagues in India, especially Professor Manjit S. Kang, Ex-VC, PAU Ludhiana, Professor Sukhpal Singh at IIM, Ahmedabad and Professor R. S. Sidhu, PAU Ludhiana for their reviews and valuable suggestions. Further, we thank all the respondents, especially the farmers, who spared much time to participate in the field survey in the hot summer season.

\section{Conflict of Interest' statement}

The authors declare that they have no conflict of interest.

\section{References}

CGWB. (2006). Dynamic Ground Water Resources of India (as on March 2004). Faridabad: Central Ground Water Board, Ministry of Water Resources, Government of India.

CGWB. (2009). Dynamic Ground Water Resources of India (as on March 2004). Faridabad: Central Ground Water Board, Ministry of Water Resources, Government of India.

CGWB. (2011). Dynamic Ground Water Resources of India (as on March 2009). Faridabad: Central Ground Water Board, Ministry of Water Resources, Government of India. 
CGWB. (2012). Ground Water Level Scenario in India (November-2012). Faridabad: Central Ground Water Board, Ministry of Water Resources, Government of India.

CGWB. (2013). Ground Water Year Book-India 2012-13. Faridabad: Central Ground Water Board, Ministry of Water Resources, Government of India.

CGWB. (2013a). Master Plan for Artificial Recharge to Ground Water in India. Faridabad: Central Ground Water Board, Ministry of Water Resources, Government of India.

CGWB, 2014. Dynamic Ground Water Resources of India (as on March 2011). Faridabad: Central Ground Water Board, Ministry of Water Resources, Government of India.

De Fraiture, C., and Giordano, M. (2014). Small private irrigation: A thriving but overlooked sector. Agricultural Water Management, 131, 167-174.

GoP. ( 2006). Statistical Abstract of Punjab. Chandigarh: Economic Advisor to Government of Punjab, Government of Punjab.

GoP. (2009). Economic Survey of Punjab 2008-09. Chandigarh: Economic Advisor to Government of Punjab,

GoP (2012). Statistical Abstract of Punjab. Chandigarh: Economic Advisor to Government of Punjab, Government

GoP (2012a). Environment Statistics of Punjab. Chandigarh: Economic Advisor to Government of Punjab, 499 Government of Punjab.

GoP. ( 2013). Statistical Abstract of Punjab. Chandigarh: Economic Advisor to Government of Punjab, Government of Punjab. challenges. Environmental Science and Policy, 51,117-124. 
Groundwater Resources in the Indian Punjab

504 Kalkat, G. S., Pannu, K.S., Singh, K., and Rangi, P.S. (2006). Agriculture and Rural Development of Punjab. 505 Chandigarh: Punjab State Farmers Commission, Government of Punjab.

506 Kulkarni, H., and Shah, M. (2013). Punjab Water Syndrome: Diagnostics and Prescriptions. Economic and Political $507 \quad$ Weekly, 48, 64-73.

508

509

510

511

512

513

514

515

516

517

518

519

520

521

522

523

524

525

Larson, N., Sekhri, S., and Sidhu, R. S. (2013). Adoption of Laser Levelers and Water-Saving in Agriculture: Report on a Follow-up Pilot Study. India: International Growth Centre.

MWR. (1991). Waterlogging, Salinity and Alkalinity, Working Group on identification of extent of affected areas and suggested remedial measures. New Delhi: Ministry of Water Resources, Government of India.

NSSO. (2005). Situation assessment survey of farmers: Access to modern technology for farming. New Delhi: National Sample Survey Organisation, Ministry of Statistics and Programme Implementation.

Palanisami, K., Kumar, S.D., Malik, R. P. S., Raman, S., Kar, G., and Mohan, K. (2015). Managing Water Management Research Analysis of Four Decades of Research and Outreach Programmes in India. Economic and Political Weekly, 50, 33-43.

Pede, V., Ward, P. S., Spielman, D. J., and Paris, T. (2012). Summary of the Agro-ecological and Socioeconomic Context for the Cereal Systems Initiative for South Asia (CSISA). CSISA Draft Report, October.

Planning Commission of India. (2013). Report of the high level expert group on water logging in Punjab. New Delhi: Planning Commission of India, Government of India.

PSFC. (2013). Agriculture Policy for Punjab. Chandigarh: Punjab State Farmers Commission, Government of Punjab.

Rodell, M., Velicogna, I., and Famiglietti, J.S. (2009). Satellite-based estimates of groundwater depletion in India. Nature, 460, 999-1002.

Sarkar, A., and Das, A. (2014). Groundwater Irrigation-Electricity-Crop Diversification Nexus in Punjab: Trends, Turning Points, and Policy Initiatives. Economic and Political Weekly. 49, 64-73. 
Shergill, H. S. (2013). Improvements in Soil Fertility in Punjab under Green Revolution: The Evidence and the Mechanisms. Journal of Agricultural Development and Policy, 23, 18-30.

Sidhu, R. S., Vatta, K., and Lal, U. (2011). Climate Change Impact and Management Strategies for Sustainable WaterEnergy-Agriculture Outcomes in Punjab. Indian Journal of Agricultural Economics, 66, 328-339

Sidhu, R. S., and Vatta, K. (n.d). Risk in Punjab Agriculture: Current Status and Emerging Issues (Unpublished paper). http://www.ncap.res.in/Agriculturalrisk\&insurance/_private/chapter4\%20pdf/4.2.pdf/4.2.1.pdf. Accessed 15 March 2015.

Sidhu, R. S., Vatta, K., and Dhaliwal, H. S. (2010). Conservation agriculture in Punjab: economic implications of technologies and practices. Indian Journal of Agricultural Economics 53, 1413- 1427.

Singh, J., and Sidhu, R. S. (2004). Factor in Declining Crop Diversification: A Case Study of Punjab. Economic and Political Weekly, 39, 5607-5610.

Singh, K. (2009). Act to Save Groundwater in Punjab: Its Impact on Water Table, Electricity Subsidy and Environment. Agricultural Economics Research Review, 22, 365-386.

Singh, K. (2012a). Electricity Subsidy in Punjab Agriculture: Extent and Impact. Indian Journal of Agricultural Economics, 67, 617-632.

Singh, K. (2011). Groundwater Depletion in Punjab: Measurement and Countering Strategies. Indian Journal of Agricultural Economics, 66, 573-589.

Singh, S. (2009a). Low Water Saving Technologies: Some Experiences from Literature and Field. http://www.cwpindia.org/Reports/pdf/REPORT_ON_LOW_WATER_SAVING_TECHNOLOGIES-IDS_JAIPUR.pdf. Accessed 16 July 2015.

Singh, S. (2012). Institutional and Policy Aspects of Punjab Agriculture: A Smallholder Perspective. Economic and Political Weekly, 47, 51-57.

Singh, S. (2013). Policy for Punjab’s Agriculture Will It Deliver? Economic and Political Weekly, 48, 21-23. 
Groundwater Resources in the Indian Punjab

549 Singh, S. (2016). Rethinking Diversification of Agriculture in the Indian Punjab: An Examination of Strategy and 550 Mechanisms. In: Singh, L., Singh, N. (Eds.), Economic Transformation of a developing economy: The experience 551 of Punjab (pp. 77-96), India: Springer.

552 Singh, S., and Benbi D. K. (2016). Punjab-Soil Health and Green Revolution: A Quantitative Analysis of Major Soil 553 Parameters. Journal of Crop Improvement 30, 323-340, doi: 10.1080/15427528.2016.1157540.

554 Sood, A. (2014). Halqa chiefs baffled over rush of applicants for tube well connection 90,000 applicants in queue, 555 annual power subsidy bill to touch a whopping Rs $670 \mathrm{cr}$. The Tribune (online), 24 February. 556 http://www.tribuneindia.com/2014/20140224/punjab.htm. Accessed 28 March 2014.

557 Srivastava, S. K., Chand, R., Raju, S.S., Jain, R., Kingsly, I., Sachdeva, J., Singh, J., and Kaur, A.P. (2015). 558 Unsustainable Groundwater Use in Punjab Agriculture: Insights from Cost of Cultivation Survey. Ind. Jn. of. $559 \quad$ Agri. Econ, 70, 365-378.

Tiwana, N. S., Jerath, N., Ladhar, S.S., Singh, G., Paul, R., Dua, D. K., and Parwana, H. K. (2007). State of 561 Environment: Punjab-2007. Chandigarh: Punjab State Council for Science \& Technology. 